\title{
THE GLOBALIZATION INDICATORS AND TOURISM DEVELOPMENT: A DYNAMIC PANEL-DATA ANALYSIS FOR MEDITERRANEAN COUNTRIES
}

\author{
DOI: 10.17261/Pressacademia.2020.1301 \\ JBEF- V.9-ISS.3-2020(6)-p.253-261
}

\section{Tuba Gulcemal}

Sivas Cumhuriyet University, Faculty of Tourism, Sivas, Turkey. tgulcemal@cumhuriyet.edu.tr, ORCID 0000-0003-4806-8568

\begin{tabular}{ll}
\hline Date Received: May 21, $2020 \quad$ Date Accepted: September 10, 2020
\end{tabular}

Gulcemal, T., (2020). The globalization indicators and tourism development: a dynamic panel-data analysis for Mediterranean countries. Journal of Business, Economics and Finance (JBEF), V.9(3), p.253-261. Permanent link to this document: http://doi.org/10.17261/Pressacademia.2020.1301 Copyright: Published by PressAcademia and limited licensed re-use rights only.

\begin{abstract}
Purpose- This study investigates how economic, social and political globalization indicators influence tourism development from 1995 to 2018 in the context of eight Mediterranean countries economies.

Methodology- A group of econometric tests; regressions with ordinary least squares (OLS), fixed effects (FE), random effects (RE), dynamic OLS, fully modified OLS, and at the end, the GMM approaches have been estimated from panel data of this study to achieve accurate and unbiased results.

Findings- Globalization factors categorized EG (economic globalisation), SG (social globalization) and PG (political globalization) exert positively significant and positive effects on tourism development in the selected countries' tourism growth. An improvement in any one of these globalization factors would mean higher tourism growth in the countries.

Conclusion- The results indicate that economic, social, and political globalization are significant factors for tourism development. Thus, this study proves that economic, social, and political integration of countries are significant driving forces behind their tourism development. Empirical findings propose that tourism sector significantly encourages economic growth. Also, the globalisation has a long-term relationship with tourism development.
\end{abstract}

Keywords: Tourism development, globalization indicators, KOF Index, panel data analysis, economic growth JEL Codes: F60, F65, F63

\section{INTRODUCTION}

The tourism sector not only makes a considerable contribution to the GDP but also plays an important role in terms of providing employment opportunities, reducing poverty, increasing income distribution, creating additional demand for goods and services, providing additional tax revenues and foreign exchange reserves for the governments.

With increasing globalization and opportunities around the world, most countries are initiating several policies to reach their targets of economic growth, and tourism has become one of the most significant tools for achieving this purpose.

This study uses annual data from 1995 to 2017 and employs a ordinary least squares (OLS), fixed effects (FE), random effects (RE), dynamic OLS, fully modified OLS and GMM for the empirical investigation. The reason for taking Mediterranean countries (Egypt, France, Greece, Italy, Morocco, Spain, Tunisia, and Turkey) as a focal point is that the recent developments in the Mediterranean region have shown that international tourist inflows could be sharply affected by external shocks (Ren, Can, et al.2019:2). Therefore, these countries should upgrade their market portfolios (inbound tourism basket) to attract tourists from richer countries. These adverse external shocks can be even more problematic for some of these countries, where economies largely depend on tourism earnings. Globalization is considered a determining factor with huge impact on tourism industry growth (Fereidouni, Al-Mulali, Najdi, 2014) as it expands the market and integrates societies; decreases geographical restrictions on socio cultural classifications (Friedman, 1999; Waters, 1995) increases the flow of people, ideas, and technologies (Albrow, 1996); and alters societies' economic, political, and cultural infrastructure. On the one hand, as a result of globalization, the tourism industry as a service trade became more sensitive to financial, economic, and political crises (Al-Rjoub, 2011; Kiani, 2011; Sinnakkannu and Nassir, 2008). On the other hand, Cohen (2012) claimed that globalization has had remarkable influence on the tourism industry's development (Javid and 
Katircioglu, 2017:1). The literature has established the relationship between globalization indicators and TAs, no attention has been given to the relationship between globalization indicators and tourism development as measured by tourism expenditures (TEs) or as tourism receipts (TRs).

This study aims to broaden the tourism literature by assessing whether globalization indicators influence tourism development. More specifically, examines whether social globalization (SG), political globalization (PG), or economic globalization (EG) affect TAs (tourism arivals), TEs (tourism expenditures) or TRs (tourism receipts). In this research, the Konjunkturforschungsstelle (KOF) Globalization Index was used to evaluate these relationships; the KOF calculation method addresses globalization's economic, social, and political aspects. This study will implement the new measures developed by the KOF Index, along with various economic, social, and political elements to more meticulously analyze how globalization indicators affect tourism development. Due to the model we use, it will also generate significant value to policy and practice regarding tourism development. And also, these data will be quite beneficial for policymakers who need to understand how globalization indicators influence tourism development.

\section{LITERATUR REVIEW}

In spite of different approaches to the globalization phenomenon, in most definitions both economy and society are the important factors underlying the basis of the globalization of the world economy. As Boğa and Erkişi mentioned (2019), comparisons between previous studies are difficult because of different periods used and the share of tourism in total economy varies in selected countries. Kosolapov N.A.(2001), defines the globalisation the intensification of the crisis phenomena and weakening of the role of the national state the tendency to the unification of the power, the global expansion of the consumption means, the solution to the local problems in the context of the global community, the flexible and multi-center character of the international relations. According to Dreher (2006): Globalization is a process that erodes national boundaries, integrates national economies, cultures, technologies and governance, and produces complex relations of mutual interdependence.Objective indicators are helpful in determining which countries are or are about to be globalized, and these include the Maastricht Globalization Index (MGI) (Martens and Zywietz, 2006), which was created by the Dutch Research Institute, and the other one globalization index produced by the KOF Swiss Economic Institute introduced by Dreher et al., 2006. (Javic ve Katırcıoğlu, 2017:3) Unlike the Maastricht Globalisation Index, KOF Index does not take into account environmental factors. It was updated in 2008 by Dreher et al. and in 2019 by Gygli et al.

Dreher (2006) emphasizes that using trade or investment to GDP as a proxy for globalization provides less robust results, while using the KOF Globalization Index as a proxy for globalization yields more robust results. Dreher (2006) examines the impact of globalization on taxation using and updating a self-developed globalization index for 30 OECD countries over the period 1970-2000. The results show that globalization has a positive effect on capital tax rates (Sevinç, Yalaman ve Sevil, 2019: 355). Tourism can be relevantly described as a composite product or a "product-system", that is made up of technologically separate components which are sequentially linked into a value added chain whose final product is sold to the tourist (Petit and Salhi, 2013). The United Nations World Tourism Organization (UNWTO) estimates that internationally there were just 25 million tourist arrivals in 1950. 68 years later this number has increased to 1.4 billion international arrivals per year. Figure 1 . shows the numbers by regions.

WTTC's (World Travel and Tourism Council) annual research shows the Travel and Tourism sector experienced 3.5\% growth in 2019 , outpacing that of the global economy $(2.5 \%)$ for the ninth consecutive year. Over the past five years, one in four new jobs were created by the sector. In 2019, Travel andTourism's direct, indirect and induced impact accounted for: US\$8.9 trillion contribution to the world's GDP, 10.3\% of global GDP, 330 million jobs, 1 in 10 jobs around the World, US\$1.7 trillion visitor exports (6.8\% of total exports, $28.3 \%$ of global services exports), US\$948 billion capital investment (4.3\% of total investment) (https://wttc.org/Research/Economic-Impact). 


\section{Figure 1: International Tourist Arrivals by World Region}

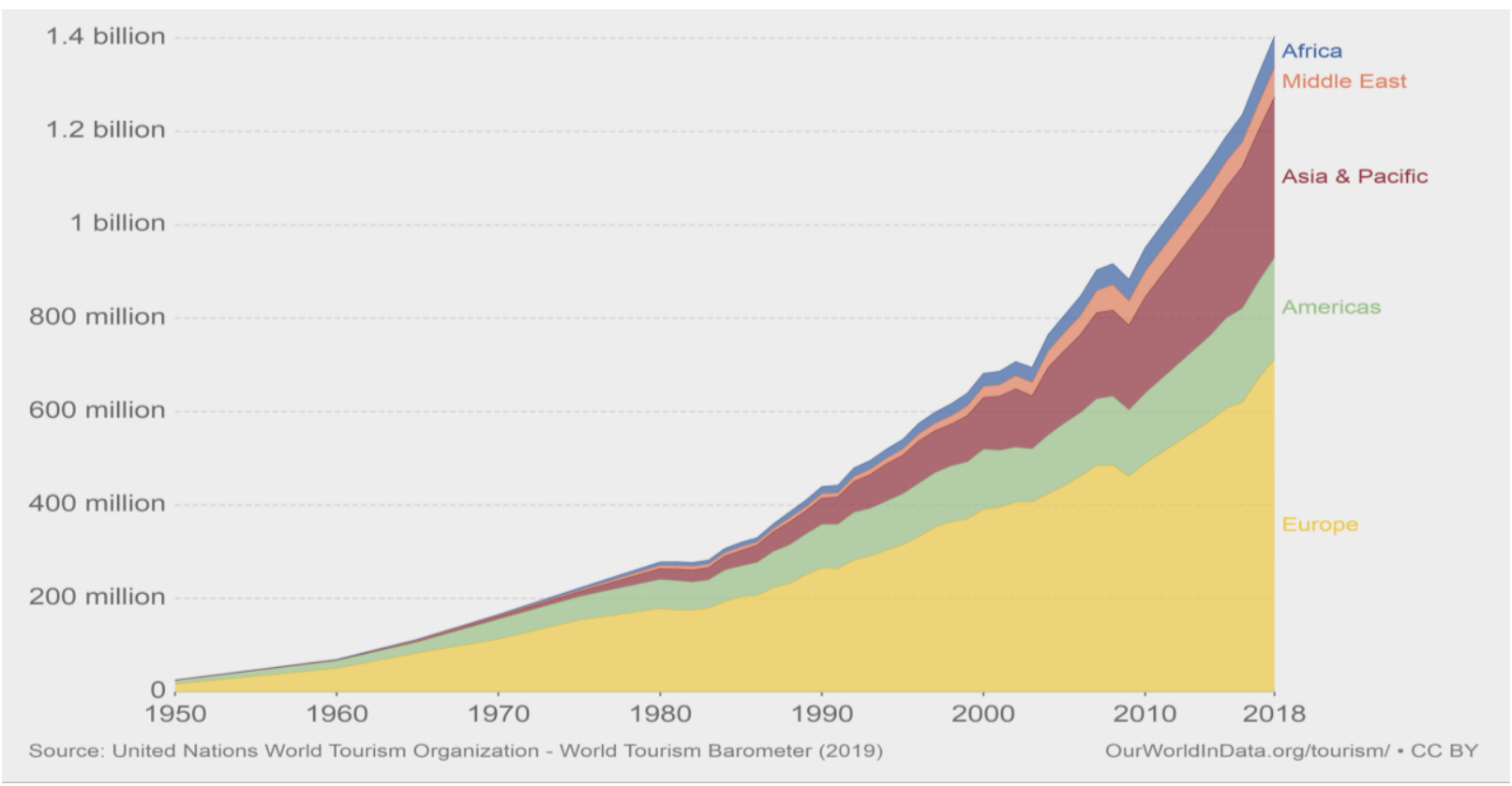

There are four approaches in tourism literature to examine the relationship between tourism and economic growth: the tourism-led growth hypothesis: tourism causes growth; the conservation hypothesis: growth causes tourism; the feedback hypothesis: bidirectional causality; and the neutrality hypothesis: no significant causality (Ren et.al.,2019:3).

Studies are particularly on the causality between tourism and economic growth and vary according to the various econometric methods using cross-sectional/panel data or time series. Seetanah (2010) found that tourism development was the main factor in explaining economic performance using a study which analyzed the relationship between tourism and economic growth in island countries by applying the Generalized Method of Moments (GMM) technique in dynamic panel data for the period of 1990-2007. Kum et al. (2015), analyzed the relationship between tourism activity and economic growth for the Future 11 countries using the data from 1995-2013 and a panel cointegration technique. They found a positive relationship between tourist arrivals and GDP. According to the results, a $1 \%$ increase in tourist arrivals increases GDP by $0.06 \%$ in the Future 11 countries. Tang and Abosedra (2014) have analyzed the impact of tourism on economic growth in 24 Middle East and North African (MENA) countries over the period 2001-2009. The findings demonstrate that tourism has a positive impact on growth. Similarly, Holzner (2011) has examined the efect of tourism on economic growth in 134 countries over the period 1970-2007 and the study concluded that tourism positively a_ects growth in the long run. In the panel data sample of 21 countries in the Mediterranean region (African, Asian and European countries), Tugcu, C.T. (2014) tested the causality (using the approach by Dumitrescu, E., I.; Hurlin, C. (2012) between tourism and growth over the period 1998-2011. The empirical results indicate that there is a bidirectional relationship between the variables of European and Asian countries. However, the paper also concludes that there is no relationship between tourism and growth in a sample of African countries.

Shahzad et al. (2017) conducted research on the top 10 tourist destinations to test the growth-cause tourism hypothesis by using the Quantile-to-Quantile (QQ) approach and a tourism index for the period 1990-2015. Although the results of the study revealed a positive relationship between these two variables, the relationship observed for China and Germany was weak. The authors attributed this result to the relatively lower share of tourism in these economies. Danish and Wang (2019) investigate the dynamic relationship between tourism, economic growth, and CO2 emissions from 1995 to 2014 in the context of BRICS economies. Empirical findings propose that tourism sector significantly encourages economic growth; however, tourism degrades the quality of the environment. Also, globalisation has a long-term relationship with economic growth but an insignificant relationship with $\mathrm{CO} 2$ emissions. The long-term elasticities further recommend that investment stimulate economic growth and mitigate $\mathrm{CO} 2$ emissions. Trunina et al. (2020) provide the globalization processes dynamics assessment in the theoretical approach and the impacts on the world travel market development. The interest of foreign tourists in Ukraine's history and culture will grow the tourism development, which will enable the country to preserve its cultural and historical heritage and to be successfully placed at the world travel market. Harun and Suprayitno (2012) examined general characteristics of Singapore's tourism industry and its role within the process of globalization. The output 
of the study has shown that the price of consumer index (Index) have influence the increasing number of tourist to Singapore (TouS) in a positive way and only the total number of hotels in Singapore is the major factor that contributed to the tourism sector's income.

\section{DATA AND METHODOLOGY}

\subsection{Model Specification and Data}

The empirical models were specifically designed as a reduced form of the dynamic panel model of tourism development. TEs, TAs, and TRs represent three different proxies for tourism development in three different models. In each model, the specific proxy was a function of globalization sub-indices: EG, PG, and SG. These factors' influence on TEs, TAs, and TRs was examined separately based on equations (1), (2), and (3). The variable, CV, is control variables added to the models of the present study. In the models $i$ denotes the country $(i=1, \ldots 8)$ and $t$ denotes the time period $(t=1995, \ldots 2017)$. Equations (1) through (3) are fairly general specifications, allowing for dynamic tourism development effects, stochastic error terms $(\varepsilon)$, fixed time effects $(\psi)$, and individual fixed country effects $(C)$. The econometric form of equations:

$$
\begin{aligned}
& \log T A_{i t}=B_{0}+\beta_{1}\left(\log E G_{i t}\right)+\beta_{2}\left(\log P G_{i t}\right)+\beta_{3}\left(\log S G_{i t}\right)+\log C V_{i+} C_{i}+\psi_{t}+\varepsilon_{i t} \\
& \log T E_{i t}=\beta_{0}+\beta_{1}(\log E G i t)+\beta_{2}\left(\log P G_{i t}\right)+\beta_{3}\left(\log S G_{i t}\right)+\log C V_{i t}+C_{i}+\psi_{t}+\varepsilon_{i t} \\
& \log T R_{i t}=\beta_{0}+\beta_{1}\left(\log E G_{i t}\right)+\beta_{2}\left(\log P G_{i t}\right)+\beta_{3}(\log S G i t)+\log C V_{i t}+C_{i}+\psi_{t}+\varepsilon_{i t},
\end{aligned}
$$

We used annual data from 8 countries between 1995 and 2018 to examine globalization's influence on tourism development. All variables were transformed into the natural logarithmic form. This section explains the econometric strategy and estimation of results.

Dependent variables: This study's dependent variable was tourism development. The literature's most commonly used measures were statistical availability and consistency between data sources, international TAs, TEs, and international TRs. (Lee and Brahmasrene, 2013; Nguyen, Nguyen and Nguyen, 2014; Ridderstaat, Oduber, Croes, Nijkamp and Martens, 2014; Saha and Yap, 2014; Song et al., 2010; Tang and Tan, 2015; Tugcu, 2014). Accordingly, this study used these three indicators to comprehensively measure tourism industry development. These data obtained from World Development Indicators.

International tourism number of arrivals (TA): International inbound tourists (overnight visitors) are the number of tourists who travel to a country other than that in which they have their usual residence, but outside their usual environment, for a period not exceeding 12 months and whose main purpose in visiting is other than an activity remunerated from within the country visited.

International tourism receipts (TR) (current US\$): International tourism receipts are expenditures by international inbound visitors, including payments to national carriers for international transport. These receipts include any other prepayment made for goods or services received in the destination country. They also may include receipts from same-day visitors, except when these are important enough to justify separate classification.

International tourism expenditures (TE) (current US\$): International tourism expenditures are expenditures of international outbound visitors in other countries, including payments to foreign carriers for international transport. These expenditures may include those by residents traveling abroad as same-day visitors, except in cases where these are important enough to justify separate classification.

Independent Variables: KOF Globalization Index's sub-components, EG (economic globalisation), SG (social globalisation) and PG (political globalisation) are our independent variables and can be downloaded form http://www.globalization.kof.ethz.ch. KOF Globalisation Index, a composite index measuring globalization for every country in the world along the economic, social and political dimension. The new index is based on 43 instead of 23 variables in the previous version (Dreher 2006; updated Dreher et.al. 2008). The new index is used to examine the effect of globalization on tourism development. The 2018 KOF Globalisation Index is based on 43 individual variables, which are aggregated to a de facto and a de jure index of five sub-dimensions (trade, financial, interpersonal, informational and cultural globalization), three dimensions (economic, social and political globalization) and covers 207 countries, one total index (Gygli et.al.2019:558). Economic globalization (EG) which is a composite measure comprising the variables: trade in goods and services, trade partner diversity, foreign direct investment, portfolio investment, international debt, international reserves, international income payments. Social globalization (SG) consists of interpersonal globalisation, informational globalisation, cultural globalisation. Political globalization (PG) characterizes the diffusion of government policies like embassies, UN peace keeping missions, International NGOs (Gygli et.al., 2019:543-546).

Control variables: The control variables of gross domestic product (GDP, $2010=100$ at dollar prices), gross fixed capital formation (GFC, $2010=100$ at dollar prices), overall population (POP), and real effective exchange rates (RER, 2010 = 100) 
have been added as in the works of Poprawe (2015) and Yap and Saha (2013). This is to avoid omitted variable problems in regressions.

Table 1: Variable Names, Symbols, Definition and Source

\begin{tabular}{|c|c|c|c|c|}
\hline Variable names & Symbol & Definition & Unit & Source \\
\hline Tourism Arrivals & TA & number of tourists & numbers & Worldbank \\
\hline Tourism Receipts & TR & $\begin{array}{l}\text { Expenditures by international } \\
\text { inbound visitors }\end{array}$ & Current US\$ & World bank \\
\hline Tourism Expenditure & $\mathrm{TE}$ & $\begin{array}{l}\text { expenditures of international } \\
\text { outbound visitors }\end{array}$ & Current US\$ & World bank \\
\hline Economic Globalisation & EC & $\begin{array}{l}\text { represents trade in goods and } \\
\text { services, trade partner } \\
\text { diversity, foreign direct } \\
\text { investment, etc. }\end{array}$ & Sub-Indice & $\begin{array}{l}\text { KOF } \\
\text { Globalisation } \\
\text { index }\end{array}$ \\
\hline Political Globalisation & PG & $\begin{array}{l}\text { a composite measure presents } \\
\text { the distribution of government } \\
\text { policies }\end{array}$ & Sub-Indice & $\begin{array}{l}\text { KOF } \\
\text { Globalisation } \\
\text { index }\end{array}$ \\
\hline Social Globalisation & SG & $\begin{array}{l}\text { Conveys how ideas, } \\
\text { information, images and } \\
\text { people progress }\end{array}$ & Sub- Indice & $\begin{array}{l}\text { KOF } \\
\text { Globalisation } \\
\text { index }\end{array}$ \\
\hline Economic Growth & GDP & $\begin{array}{l}\text { Gross domestic product is } \\
\text { used for calculation of } \\
\text { economic growth }\end{array}$ & Current US\$ & World bank \\
\hline Population & POP & $\begin{array}{l}\text { Total population is based on } \\
\text { the defacto definition of }\end{array}$ & numbers & World bank \\
\hline Reel Exchange rate & $\mathrm{RE}$ & population & $2010=100$ at $\$$ price & World bank \\
\hline Gross Fixed Capital & GFC & $\begin{array}{l}\text { Index } \\
\text { gross domestic fixed } \\
\text { investment includes land } \\
\text { improvements (fences, } \\
\text { ditches, drains, and so on); } \\
\text { plant, machinery, and } \\
\text { equipment purchases etc. }\end{array}$ & Current US\$ & World bank \\
\hline
\end{tabular}

\section{FINDINGS AND DISCUSSIONS}

This study has employed different panel estimation methods for regressions of Equation (1) through (3) in order to control for robustness of results. Therefore, regressions with ordinary least squares (OLS), fixed effects (FE), random effects (RE), dynamic OLS, fully modified OLS, and GMM approaches have been estimated from panel data of this study. Equations (1) through (3) are examples of the linear dynamic panel model introduced by Blundell and Bond (1998). Their GMM method solves likely crosssection dependence and endogeneity problems in a regression model. The GMM method can also solve other problems that make the estimation inconsistent - for example: (1) autocorrelation problems due to lagged dependent variables and (2) a small sample size or a large number of cross sections. It is important to mention that prior to these estimations, standard panel unit root tests will be carried out to see if data generating process of series are stationary. Panel estimates for the 8 countries' tourism development are presented in Tables 3, 4 and 5.

The presence of non-stationary data leads to meaningless results, so it is important to check the level of stationarity for underlying variables. According to correlation matrix of tourism development indicators are not generally and highly correlated. Therefore, no autocorrelation problems are expected. And four different unit root tests applied to check whether or not the data were stationary. According to the results as seen Table 2, all of the variables seem to be stationary at their level forms especially based to Levin, Lin and Chu test. 
Table 2: Unit Root Test Results

\begin{tabular}{|l|c|c|c|c|}
\hline Variables & Levin, Lin and Chu t* & $\begin{array}{c}\text { Im, Pesaran and } \\
\text { Shin W-stat }\end{array}$ & ADF-Fisher Chi-square & PP-Fisher Chi-square \\
\hline InEG & -3.8733 & -3.3580 & 47.4271 & $(0.0001)$ \\
& $(0.0001)$ & $(0.0004)$ & 27.6781 & 0.0002 \\
\hline InSG & -5.6598 & -2.1809 & $(0.0345)$ & 27.8625 \\
& $(0.0000)$ & $(0.0146)$ & 22.2529 & $(0.0328)$ \\
\hline InPG & -4.3484 & -1.6708 & $(0.1352)$ & 12.5777 \\
& $(0.0000)$ & $(0.0474)$ & 12.5541 & $(0.7033)$ \\
\hline InTR & -2.5139 & 0.1470 & $(0.7050)$ & 10.7922 \\
& $(0.0060)$ & $(0.5584)$ & 13.2127 & $(0.8221)$ \\
\hline InTE & -1.4499 & 0.9237 & $(0.6571)$ & 10.8323 \\
& $(0.0735)$ & $(0.8222)$ & 11.0742 & $(0.8197)$ \\
\hline InTA & -2.0326 & 0.9071 & $(0.8049)$ & 10.1186 \\
& $(0.0210)$ & $(0.8178)$ & 6.8818 & $(0.8604)$ \\
\hline InGDP & -1.3882 & 1.0720 & $(0.9755)$ & $(0.6543$ \\
& $(0.0825)$ & $(0.8581)$ & 14.6287 & $8.3585)$ \\
\hline InGFC & -2.1925 & 0.4344 & $(0.5520)$ & $(0.9382)$ \\
& $(0.0142)$ & $(0.6680)$ & -1.6194 & -1.9738 \\
\hline InPOP & 4.0466 & 4.5401 & $(0.9473)$ & $(0.9758)$ \\
& $(1.0000)$ & $(1.0000)$ & 15.4329 & 16.0644 \\
& & & $(0.4932)$ & $(0.4485)$ \\
\hline InRE & -0.0456 & 0.1277 & & \\
& $(0.4818)$ & $(0.5508)$ & & \\
\hline
\end{tabular}

Note: The figures in the parentheses show the $p$-values.

Table 3 reports the regression results of Equation (1). Globalization factors variables (EG, SG, and PG) generally exert positively significant effects on tourist arrivals across different methodological regressions. There are some negative signs for their coefficients but are not statistically significant. This is to conclude that no matter what approach is selected for Equation (1), the effects of EG, SG and PG factors on tourist arrivals are positively significant.

Table 3 also shows that control variables of this study (GDP, POP, and RE) do also exert statistically significant effects on tourist arrivals to the selected 8 countries. The signs of coefficient for real exchange rates with respect to tourist arrivals are negative as expected.

Table 3: The Effects of Globalization Factors on Tourist Arrivals

\begin{tabular}{|c|c|c|c|c|c|c|c|c|c|c|}
\hline \multicolumn{11}{|c|}{ Dependent variable } \\
\hline $\begin{array}{l}\text { Independent } \\
\text { variables }\end{array}$ & OLS & FE & RE & $\begin{array}{l}\text { DOLS } \\
\text { None }\end{array}$ & $\begin{array}{c}\text { DOLS } \\
\text { With } \\
\text { constant }\end{array}$ & $\begin{array}{l}\text { DOLS } \\
\text { With } \\
\text { trend }\end{array}$ & $\begin{array}{l}\text { FMOLS } \\
\text { None }\end{array}$ & $\begin{array}{c}\text { FMOLS } \\
\text { with } \\
\text { constatnt }\end{array}$ & $\begin{array}{c}\text { FMOLS } \\
\text { with } \\
\text { trend }\end{array}$ & GMM \\
\hline Intercept & -0.021 & -0.001 & 0.020 & & & & & & & 0.518 \\
\hline InEG & 0.000 & 0.000 & 0.000 & 0.0029 & -0.3634 & 0.3905 & 0.000 & 0.0000 & 0.0000 & 0.109 \\
\hline InSG & 0.000 & 0.000 & 0.000 & 0.0000 & 0.1510 & -0.525 & 0.000 & 0.0000 & 0.0000 & 0.110 \\
\hline InPG & -0.021 & -0.595 & 0.020 & -0.000 & 0.9900 & -0.138 & -0.000 & -0.0312 & 0.7948 & -0.803 \\
\hline InGDP & 0.000 & -0.267 & 0.000 & -0.207 & -0.1917 & 0.3989 & 0.000 & -0.0207 & 0.0014 & 0.409 \\
\hline InGFC & 0.470 & 0.016 & 0.469 & 0.0178 & 0.0042 & -0.304 & 0.058 & 0.0000 & 0.1266 & 0.011 \\
\hline InPOP & 0.001 & 0.001 & 0.001 & 0.0000 & 0.1263 & 0.6146 & 0.000 & 0.0000 & 0.0000 & 0.766 \\
\hline InRE & 0.743 & 0.000 & 0.743 & & & & -0.000 & 0.0000 & 0.1791 & -0.004 \\
\hline AR (-2) & & & & & & & & & & 0.4480 \\
\hline
\end{tabular}




\begin{tabular}{|l|l|l|l|l|l|l|l|l|l|l|}
\hline Adj. $\mathbf{R}^{2}$ & 0.9502 & 0.8405 & 0.9520 & 0.9928 & 0.9920 & 0.9945 & 0.949 & 0.9777 & 0.9900 & \\
\hline Wald Chi 2 & & & & & & & & & & 88560.4 \\
\hline S.E. of Reg & 0.2292 & .15234 & .152342 & 0.0846 & 0.0892 & 0.0741 & 0.2289 & 0.1513 & 0.1012 & \\
\hline F-prob. & 0.0000 & 0.0000 & 0.0000 & & & & & & & 0.0000 \\
\hline Long runvar & - & & & 0.0003 & 0.0001 & $2.64 \mathrm{E}-$ & 0.006 & 0.0047 & 0.0025 & \\
\hline Obs. & 192 & 192 & 192 & 168 & 168 & 168 & 184 & 184 & 184 & 184 \\
\hline
\end{tabular}

Note: For DMOLS, we had to decrease the number of indipendent variables.

Table 4 reports the regression results of Equation (2) where TRs are dependent variable. The variables of globalization factors (EG, SG, and PG) again generally perform positively significant effects on TRs across different methodological regressions. This is to conclude for Equation (2), the effects of EG, SG, and PG factors on tourist receipts are positively significant no matter what approach is selected. Table 4 also shows that control variables of this study (GDP, POP, and RE) do also exert statistically significant effects on TRs of the selected 8 countries.

Tablo 4: The Effects of Globalization Factors on Tourism Receipts

\begin{tabular}{|l|l|l|l|l|l|l|l|l|l|l|}
\hline \multicolumn{2}{|c|}{$\begin{array}{l}\text { Dependent variable } \\
\text { LnTR }\end{array}$} \\
\hline $\begin{array}{l}\text { Indep. } \\
\text { variables }\end{array}$ & OLS & FE & RE & $\begin{array}{l}\text { DOLS } \\
\text { None }\end{array}$ & $\begin{array}{l}\text { DOLS } \\
\text { With } \\
\text { constant }\end{array}$ & $\begin{array}{l}\text { DOLS } \\
\text { With } \\
\text { trend }\end{array}$ & $\begin{array}{l}\text { FMOLS } \\
\text { None }\end{array}$ & $\begin{array}{l}\text { FMOLS } \\
\text { with } \\
\text { constant }\end{array}$ & $\begin{array}{l}\text { FMOLS } \\
\text { with } \\
\text { trend }\end{array}$ & GMM \\
\hline Intercept & -0.126 & -0.003 & -0.124 & & & & & & & -0.214 \\
\hline InEG & 0.000 & 0.000 & 0.000 & 0.0206 & -0.0574 & 0.0006 & 0.0000 & 0.0000 & 0.0000 & 0.032 \\
\hline InSG & 0.000 & 0.830 & 0.000 & 0.0006 & 0.0178 & -0.0011 & 0.0000 & 0.7470 & 0.5369 & 0.188 \\
\hline InPG & 0.610 & 0.015 & 0.609 & 0.0049 & 0.4159 & -0.0007 & -0.3140 & 0.0001 & 0.0000 & 0.357 \\
\hline InGDP & 0.000 & 0.000 & 0.000 & 0.5643 & 0.7676 & 0.0005 & 0.0000 & 0.0000 & 0.0000 & 0.001 \\
\hline InGFC & 0.000 & 0.000 & 0.000 & 0.0020 & 0.0000 & -0.0008 & 0.0000 & 0.0000 & 0.7647 & 0.000 \\
\hline InPOP & 0.000 & 0.078 & 0.000 & 0.0029 & 0.4748 & 0.0009 & 0.0000 & 0.0031 & -0.2765 & 0.123 \\
\hline InRE & -0.125 & 0.198 & -0.124 & & & & -0.0000 & 0.0091 & -0.0006 & -0.024 \\
\hline AR (-2) & & & & & & & & & & 0.7436 \\
\hline Adj. R & 0.953 & 0.867 & 0.9549 & 0.99198 & 0.99675 & 0.99998 & 0.95283 & 0.97859 & 0.98730 & \\
\hline $\begin{array}{l}\text { Wald } \\
\text { Chi2 }\end{array}$ & & & & & & & & & & 45692. \\
\hline $\begin{array}{l}\text { S.E. of } \\
\text { Reg }\end{array}$ & .2527 & .9618 & .17407 & 0.10217 & 0.06501 & 0.00465 & 0.25075 & 0.16892 & 0.13009 & \\
\hline F-prob. & 0.000 & 0.000 & 0.0000 & & & & & & & 0.0000 \\
\hline $\begin{array}{l}\text { Long run } \\
\text { var. }\end{array}$ & & & & 0.00073 & $8.59 \mathrm{E}-05$ & $8.60 \mathrm{E}-08$ & 0.00836 & 0.00715 & 0.00559 & \\
\hline Obs. & 192 & 192 & 192 & 168 & 168 & 168 & 184 & 184 & 184 & 184 \\
\hline
\end{tabular}

Finally, Table 5 reports the regression results of Equation (3) where TEs are dependent variable. The variables of globalization factors (EG, SG, and PG) again generally exert positively significant effects on TEs across different methodological regressions. This is to conclude that no matter what approach is selected for Equation (3), the effects of EG, SG, and PG factors on TEs are again positively significant. Table 5 also shows that control variables of this study (GDP, POP, and RE) do also exert statistically significant effects on TEs of the selected 8 countries.

Tablo 5: The Effects of Globalization Factors on Tourism Expenditures

\begin{tabular}{|l|l|l|l|l|l|l|l|l|l|l|}
\hline \multicolumn{10}{|c|}{$\begin{array}{l}\text { Dependent variable } \\
\text { LnTE }\end{array}$} \\
\hline $\begin{array}{l}\text { Indep. } \\
\text { variables }\end{array}$ & OLS & FE & RE & $\begin{array}{l}\text { DOLS } \\
\text { None }\end{array}$ & $\begin{array}{l}\text { DOLS } \\
\text { With } \\
\text { const. }\end{array}$ & $\begin{array}{l}\text { DOLS } \\
\text { With } \\
\text { trend }\end{array}$ & $\begin{array}{l}\text { FMOLS } \\
\text { None }\end{array}$ & $\begin{array}{l}\text { FMOLS } \\
\text { with } \\
\text { const. }\end{array}$ & $\begin{array}{l}\text { FMOLS } \\
\text { with } \\
\text { trend }\end{array}$ & GMM \\
\hline Intercept & -0.000 & -0.000 & -0.000 & & & & & & & -0.500 \\
\hline InEG & 0.000 & 0.000 & 0.000 & 0.0002 & 0.1548 & 0.0022 & 0.0000 & 0.0000 & 0.0004 & 0.000 \\
\hline
\end{tabular}




\begin{tabular}{|l|l|l|l|l|l|l|l|l|l|l|}
\hline InSG & 0.000 & -0.417 & 0.000 & 0.0373 & 0.6478 & -0.0044 & 0.0000 & -0.2145 & 0.0005 & 0.207 \\
\hline InPG & -0.915 & 0.003 & -0.915 & 0.0000 & 0.2758 & -0.6056 & -0.0000 & 0.0000 & 0.1438 & -0.311 \\
\hline InGDP & 0.000 & 0.000 & 0.000 & 0.0001 & 0.0098 & 0.0021 & 0.0000 & 0.0000 & 0.0000 & 0.000 \\
\hline InGFC & -0.016 & -0.001 & -0.015 & 0.1052 & 0.2751 & -0.0028 & 0.0001 & -0.0000 & -0.0000 & -0.000 \\
\hline InPOP & 0.000 & 0.000 & 0.000 & 0.1602 & 0.7449 & 0.0040 & 0.0000 & 0.0000 & 0.0874 & 0.085 \\
\hline InRE & 0.000 & 0.824 & 0.000 & & & & -0.1569 & -0.5763 & -0.1507 & 0.716 \\
\hline AR (-2) & & & & & & & & & & 0.5262 \\
\hline Adj. R & 0.9720 & 0.8839 & 0.9730 & 0.9939 & 0.99646 & 0.9999 & 0.9565 & 0.98854 & 0.9900 & \\
\hline Wald Chi2 & & & & & & & & & & 13853.7 \\
\hline S.E. of Reg & .25174 & .98751 & .16426 & 0.1152 & 0.08830 & 0.0111 & 0.3113 & 0.15995 & 0.1487 & - \\
\hline F-prob. & 0.0000 & 0.0000 & 0.0000 & & & & & & & 0.0000 \\
\hline $\begin{array}{l}\text { Long run } \\
\text { var. }\end{array}$ & & & & 0.00066 & 0.00018 & $5.83 \mathrm{E}-07$ & 0.01149 & 0.00820 & 0.00586 & \\
\hline Obs. & 192 & 192 & 192 & 168 & 168 & 168 & 184 & 184 & 184 & 184 \\
\hline
\end{tabular}

Note: According to Hausman test Prob>chi2 $=0.0000$, so Fixed Effect model is more suitable.

\section{CONCLUSION}

Results suggest that globalization factors categorized EG, SG, and PG trends in the globe exert positively significant and positive effects on tourism development in the selected countries' tourism growth. Therefore, to ensure a solid growth performance, the policymakers in these countries can implement some policies to upgrade the income level of a country's tourist arrivals. Indeed, the economic growth performance of some countries in the panel dataset is mainly based on the tourism sector. In addition to this other factors such as climate change, country size, economic policies, historical relationships (common language, common religion), political instability and real exchange rates can play a significant role in the income level of a country's tourist arrivals. Economic or political cooperation can also build up transculturation that can also positively affect the level of income level of a country's tourist arrivals.

An improvement in any one of these globalization factors would mean higher tourism growth in the countries. And country-specific economic aggregates such as gross domestic product, gross fixed capital, population and real exchange rates are important and significant contributors to these effects.

Tourism is a luxury good, and therefore, the income elasticity of the international tourism demand is larger than one and the tourists in the low-income countries can show a more negative reaction to adverse conditions than those of the countries attracting tourists like our sample. A decline in tourism revenue, and its negative effects on economic performance, will bring more problems to developing countries, especially developing countries whose economies mainly depend on tourism revenue. The visa liberalization policy for high-income economies can upgrade the income level of their tourist inflows and this can sustain economic and environmental performance. Providing a stable tourism revenue is one of the most significant sources of foreign exchange earnings. Therefore, the income level of their tourist inflows can also associate with the volatility of exchange rate earnings because a higher level of income level of a country's tourist arrivals can make the real value of the exchange rate less volatile. Consequently, upgrading tourism revenue can also ensure less volatile exchange rate markets. However, the exchange rate system (e.g., the flexible or fixed systems) can also affect the value of the income level of a country's tourist arrivals, and this issue also merits a future study. With its geographical location, Turkey, which is in a strategic position, but also a country with deep historical and cultural relations with the countries of the world, it is inevitable that presence in close relationships with international economic organizations in the globalization process by staying out of this development.

\section{REFERENCES}

Boğa, S. ve Erkişi, K. (2019). The relationship between international tourism receipts and economic growth in asia pacific countries: A panel data analysis. The Academic Elegance, 6(11), pp.31-46.

Danish and Zhaohua Wang (2019). Dynamic relationship between tourism, economic growth, and environmental quality. Journal of Sustainable Tourism, pp.1-17. https://doi.org/10.1080/09669582.2018.1526293.

Dreher, A. (2006). Does globalization affect growth? Evidence from a new index of globalization. Applied Economics, 38(10), $1091-1110$.

Dreher, A., Gaston, N., and Martens, P. (2008). Measuring globalisation - gauging its consequences. New York: Springer

Dumitrescu, E.-I.; Hurlin, C. (2012). Testing for Granger non-causality in heterogeneous panels. Economic Modelling, 29(4),1450-1460

https://doi.org/10.1016/j.econmod.2012.02.014 
Gygli, Savina, Florian Haelg, Niklas Potrafke and Jan-Egbert Sturm (2019). The KOF Globalisation Index - Revisited. The Review of International Organizations, 14(3), 543-574. https://doi.org/10.1007/s11558-019-09344-2

Harun, A. and Eko, Suprayitno (2012). The important factors of tourism development in Singapore. https://www.researchgate.net/publication/322910876,1-15. doi: 10.18860/iq.v0i0.1736

Holzner, M. (2011). Tourism and economic development: The beach disease?. Tourism Management, 32(4), 922-933. https://doi.org/10.1016/j.tourman.2010.08.007

Javid, Elyeh and Salih, Katircioglu (2017). The globalization indicators-tourism development nexus: a dynamic panel-data analysis, Asia Pacific Journal of Tourism Research, DOI: 10.1080/10941665.2017.1378240

Kosolapov, N.A .(2001). The international political organization of the globalized world: models for a medium-term prospect. Social sciences and modernity, 6, 141-143.

Kum, H., Aslan, A. and Gungor, M. (2015). Tourism and Economic Growth: The Case of Next-11 Countries. International Journal of Economics and Financial Issues, 5(4), 1075-1081.

Nowak, J.J. and Petit, Sylvain and Sahli, Mondher. (2013). Globalisation in tourism: A Theoretical and empirical trade examination. 1-51, 10.1142/9789814327084_0025 https://www.researchgate.net/publication/305147345.

Pesaran, M. H. (2004). General diagnostic tests for cross section dependence in panels. Cambridge Working Papers in Economics 0435, 3, 1-39. doi:https://doi.org/https://ideas.repec.org/p/cam/camdae/0435.html

Ren, Taizeng, Can, M., Paramati, S. R., Fang, J., and Wu, W. (2019). The Impact of Tourism Quality on Economic Development and Environment: Evidence from Mediterranean Countries. Sustainability, 11(8), 2296. MDPI AG. Retrieved from http://dx.doi.org/10.3390/su11082296

Roser, Max (2020). "Tourism". Published online at OurWorldInData.org. Retrieved from: https://ourworldindata.org/tourism

Seetanah, B. (2010). Assessing the Dynamic Economic Impact of Tourism for Island economies. Annals of Tourism Research, 38(1), 291-308.

Sevinç, Deniz, Öz-Yalaman, G. ve Güven, S. (2019). The impact of globalization on corporate taxation: evidence from the kof globalization index. Journal of Research in Economics, Politics and Finance, 4(3): 350-369.

Shahzad, S. J. H., Shahbaz, M., Ferrer, R. and Kumar, R. R. (2017). Tourism-led Growth Hypothesis in the Top Ten Tourist Destinations: New Evidence Using the Quantile-on-Quantile Approach. Tourism Management, 60, 223-232

Tang, C.F. and Abosedra, S. (2014). The impacts of tourism, energy consumption and political instability on economic growth in the MENA countries. Energy Policy, 68, 458-464. https://doi.org/10.1016/j.enpol.2014.01.004

Trunina, I. M., Olena, Anatoliivna Sushchenko, Viktoriia, Valeriivna Druzhynina and Olena Leonidivna Zahorianska (2020). Globalization impact on the world travel market development, SHS Web of Conferences 73, 01029. https://doi.org/10.1051/shsconf/202073010 29

Tugcu, C.T. (2014). Tourism and economic growth nexus revisited: A panel causality analysis for the case of the Mediterranean Region. Tourism Management, 42, 207-212. https://doi.org/10.1016/j.tourman.2013.12.007

Westerlund, J. (2007). Testing for error correction in panel data. Oxford Bulletin of Economics and Statistics, 69,709-748. doi:10.1111/j.1468-0084.2007.00477.x 